\title{
Література:
}

1. Геоботанічне районування Української РСР. Київ : Наук. думка, 1977. $303 \mathrm{c}$.

2. Природно-заповідний фонд Сумської області: Атлас-довідник. Київ : ТОВ «Українська Картографічна Група», 2019.96 с.

3. Офіційні переліки регіонально рідкісних рослин адміністративних територій України (довідкове видання). Київ: Альтерпрес, 2012. 148 с.

4. Ботанічні заказники Сумської області. : веб-сайт. URL: https://uk.погода-синоптик.pp.ua > .. (дата звернення 20.12.2021).

DOI https://doi.org/10.30525/978-9934-26-183-1-3

\section{ECOLOGICAL AND HISTORICAL ANALYSIS OF THE FLORA OF THE KREMENETS MOUNTAINS NATIONAL NATURAL PARK}

\author{
Lisova N. 0. \\ Candidate of Biological Sciences, \\ Associate Professor at the Department of Geoecology and Methods \\ of Teaching Environmental Sciences \\ Ternopil Volodymyr Hnatiuk National Pedagogical University
}

Syvyj M. Ya.

Doctor of Geographic Sciences, Professor at the Department of Geography and its Teaching Methods

Ternopil Volodymyr Hnatiuk National Pedagogical University

Havryshok B. B.

Candidate of Geographic Sciences, Associate Professor at the Department of Geography and its Teaching Methods

Ternopil Volodymyr Hnatiuk National Pedagogical University

Ternopil, Ukraine

Nature reserve areas are of important phytocenotic, ecological, historical, landscape-aesthetic, educational and even economic importance. One of these are the Kremenets Mountains National Nature Park. 
Proceeding from the ecosystem position, the preservation of the genofond can be ensured only when at least the geobiocoenosis, of which it is a component, and the ecotopes corresponding to them, or entire landscapes, as is customary in Europe, are protected [1].

The flora of the study area is characterized by a variety of life forms (Fig. 1). Phanerophytes (trees and shrubs) are 74 species (9\%). Hamephytes are 25 species (3\%): Helianthemum canum, Calluna vulgaris, Rhodococcum vitisidaea, Orthilia secunda, Pyrola media, P. rotundifolia, Vinca minor, Thymus serpyllum, Th. pulegioides, Th. Marchallianus., ect. Hemicryptophytes are 428 species (51.9\%): Dracocephalum austriacum, Astrantia major, Phyllitis scolopendrium, ect. Therophytes are 228 species (27.6\%): Anagallis arvensis, Xanthium strumarium ,Papaver rhoeas, P. argemone, Bidens tripartita L., Herniaria glabra L. ect. There are 70 species of cryptophytes (8.5\%). This includes most types of families Liliaceae, Iridaceae, Alliaceae, Orchidaceae [2].

When studying the specificity of the flora of a certain region, the phenomenon of endemism is of great importance. The proportion of endemics in a particular flora characterizes the degree of individuality of a given flora. An indicator of the originality of a particular flora is the presence of a significant number of endemics. The problem of flora endemism is one of the most important indicators in plant geography, both in the scientific and practical sense.

The age of the phytobiota of the Kremenets Mountains National Nature Park can be attributed to the middle Miocene. Already in the lower Tortonian, the ecologically determined development of the flora proceeded in the direction of creo- and xerophytization. In the Upper Miocene and at the beginning of the Pliocene, a dissected landscape with forest-steppe vegetation was formed.

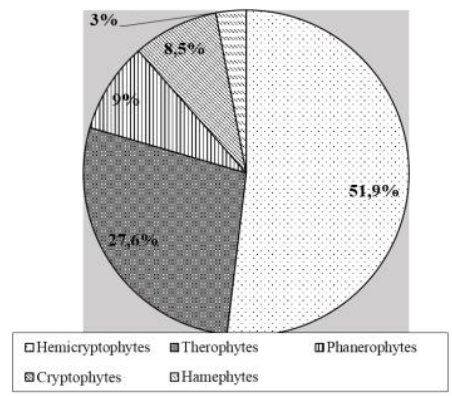

Fig. 1. The ratio of life forms of plants in the Kremenets Mountains National Nature Park 
By the middle of the Pliocene, the forest-steppe flora in the region was replaced by the steppe flora, and calceopetrophyton developed. The next mesophytization of the climate, the invasion of the coreal flora forced the plant remains of the favorable period to migrate to the storages - steep, heavily projected slopes with a calcium substrate. The Pliocene was characterized by the development of the calceo-xeromorphic complex with the transformation of the ancient subtropical-forest complex into a modernized xeromesophytic temperate forest complex. During the Pleistocene, the flora underwent several periods of cooling and warming. The results of studying the genesis of the flora indicate that during the Pleistocene, under conditions of a dissected relief, there were constant changes in the ecological conditions of a microrefugium nature, which contributed to the preservation of many ancient species $[3,4]$.

During the last millennium, two complexes of adventive plants have been formed: archaeo- and neophytes. Endemic species of different ages were formed on the basis of the autochthonous nucleus.

The leading genesis complexes of flora formed at the end of the Pliocene. Then the nemoral, calceopetrophilic, psamophilic, hydrophilic, savanoidmeadow-steppe flora was formed. After xero-cryophytic transformation during the Pleistocene, a steppe complex is formed, a complex of coniferous and birch forests, which acquired a modern composition in the Holocene [4].

In the studied territories, we identified 32 relics (3.9\% of the total number of species), of which 7 species are tertiary relics, 25 species are glacial and interglacial, and 60 are endemic ( $7.2 \%$ of the total). The richest in the number of natural endemic species are the families Orchidaceae -10 species, Rosaceae -10 species, Poaceae -9 species, Lamiaceae -7 species.

Most of the endemic species are coenoelements of calceopetrophyton, calceopetrophilic meadow-steppe areas, steppe and calceopetrophilic shrub groups. The formation of the main autochthonous core of the flora took place in the depths of the old paleocalcepetrophyton, on the basis of which the main primordial complexes arose: savanoid-meadow-steppe, ancient-steppe, and ancient-shrub. The second basis for the formation of one of the main components of the flora was the prsnemoral and prashrub.

The approximate time of the emergence and formation of paleoendems of the flora of the studied territories refers to the period from the Middle to Upper Miocene and the beginning of the Pleistocene, these are such species as Galium exoletum, Minuartia aucta, Jurinea pachysperma, etc. In their depths appeared: Euphorbia volhynica, Galium besseri, Salvia cremenecensis, Betula klokovii, etc. The group of mesochronoendemics is determined by the period 
from the beginning of the Pliocene to the middle of the Pleistocene, these include Salvia dumetorum, Chamaecytisus blockianus.

In the group of paleoendemics, the oldest, which have ancient subthetic roots, indicate the connection of our flora in the past with the ancient Mediterranean. Some of the endemics are associated with the deciduous forests of Central Europe.

\section{References:}

1. Krystyna Falińska. Ekologia roślin: Wyd. 3, popr. i uzup., 3 dodr. Warszawa, 2012. 245 st.

2. N. Lisova, M. Syvyj, O.Volik, Ecological analysis of the flora of the Kremenets Mountains National Nature Park (on the example of the mountains Divochi Skeli, Strakhova, Masliatyn, Chercha, Zamkova, Bozha), ICSF 2021: Second International Conference on Sustainable Futures: Environmental, Technological, Social, and Economic Matters, Kryvyi Rih National University, Kryvyi Rih, Ukraine (May 19-21, 2021). DOI: $10.1051 / \mathrm{e} 3$ sconf $/ 202128011008$

3. Заверуха Б. В. Флора Волыно-Подолии и ее генезис. К.: Наук. думка, 1985. $191 \mathrm{c}$.

4. Заверуха Б. В. Реліктові та ендемічні рослини Кременецьких гір та необхідність ї охорони. Охороняйте рідну природу. К.: Урожай, 1964. C. 69-78. 